\title{
TEAM-BASED LEARNING IN BUSINESS ENGLISH IN LATVIA AND EU
}

\author{
Jelena Stepanova \\ University of Latvia, Management College, Latvia
}

\begin{abstract}
Business English is among of the core subjects in business education. The application of pertinent teaching-learning approach, such as team-based learning, allows students to engage into educational process and to demonstrate higher achievements in discipline acquisition. The article reflects the results of 4-year empirical research on team-based learning implementation in Business English in several higher institutions in Latvia, where participated 298 students, who mastered their skills and competences reaching an academic success through this approach. As well the article investigates the results of empirical research on team-based learning application in other European Union universities by Business English teachers from Germany, Austria, Slovenia, Italy, Spain, Greece and France. Team-based learning in teaching Business English proved to be a successful tool as it assisted to academic success in discipline, communication and understanding of the business environment peculiarities through teamwork and critical thinking and majority of students gave positive feedback. The research demonstrated that team-based learning gives more freedom and authorizes students to be more responsible for their own studies and knowledge as the process involves both individual work and teamwork and the contribution to the team is significantly important there. Self-determination in studies leads to an academic success towards life-long competences and proves team-based learning approach to be a useful and transformative tool for teaching Business English. However, in spite of this, the results of research demonstrated the team-bases learning approach is not familiar in EU universities, although other approaches are broadly applied.
\end{abstract}

Keywords: team-based learning, Business English, EU universities, educators, transformative learning.

\section{Introduction}

There is a common feeling that "learning is a change process of societies and individuals" (Bourdieu, 1990), the ability to change the society and individuals is dependent on learning process properly arranged by the educator. The nowadays learning process even being smoothly adjusted to the needs of society in theory, in real educational practice is far from 
ideal. The peculiarities of the modern adult learning are tightly connected with the need to educate the capable workers. Thus, it is obvious that learning should be carefully planned and implemented by the educator to assist the learners in their studies to lead them to their academic achievements and in training their skills for lifelong. The entire skills for lifelong learning include the acquisition of higher level cognitive skills, ability to learn independently and be self-determined in learning in lifetime, ability to apply the course content in other various complex situations and on top of this - the ability to communicate and collaborate in teams, i.e. practical activities supported by group discussion form the core of such pedagogical practices" (Merriam and Caffarela, 2007, p.262).

Team-based learning (TBL) is such a concept in the $21^{\text {st }}$ century pedagogy, which allows educators as to lead students to academic achievements as well as to train them in their skills for lifelong (Branney and PriegoHernandez, 2018; Wu et al., 2018; Simonson, 2014; Betta, 2016; Liu and Beaujean, 2017; Balan et al., 2015; Huggins and Stamatel, 2015; Imazeki, 2015; Stein et.al, 2016; Bouw et al., 2015; Yoon, 2014). TBL incorporates various theories of adult learning, such as cooperative theory (May and Doob, 1937), theory of margin (McClusky, 1970), three dimensions of learning model (Illeris 2004), model of learning process (Jarvis, 2004), lifelong and self-directed learning (Tough, 1967), transformational learning (Mezirov, 1991) and pedagogies of engagement (Edgerton, 2001) (Nagaswami, 2011) and allows students to advance their knowledge and skills through accommodative or transcendental learning. Team-based learning is a special approach to the use of small groups that take both teaching and learning to a whole new level of educational significance (Fink, 2002, p.4). When using properly TBL as a constructivism didactic model, it drives 4 kinds of transformation:

1. It transforms small groups into teams;

2. It transforms a technique into a strategy;

3. It transforms the quality of students' learning;

4. It transforms the joy of teaching (for teachers).

There are two major distinctive features: (a) teams, instead of groups, and (b) strategy, instead of technique. TBL is a particular instructional strategy that is designed to support the development of high-performance learning teams and to provide opportunities for these teams to engage in significant learning tasks (Fink, 2002, p.9). Being an instructional strategy, it provides a set of learning activities in a particular sequence, which work synergistically to create a high level of energy on the part of the students that can be applied to the task of learning. When implemented properly, a good strategy can generate a very powerful level of educational energy. In order to use TBL, a course has to satisfy two conditions: 
1. The course should contain a significant body of information, it means the content of the course should be meaningful for the students (it emphasises constructivism background of TBL);

2. The main goal of the course - students have to learn how to apply this context by solving problems, answering questions, resolving issues successfully applying higher level cognitive skills in the new context.

In order to build high performance learning teams in TBL, the teacher should arrange the following conditions:

1. Form the groups properly, i.e. groups should be diverse (in the frames of this research as in language level, as in other issues, as gender, race, ethnicity, previous knowledge, work experience, personal characteristics etc, what is defined on the first lesson via pre-course questionnaires);

2. Keep the groups together during the term to give a chance to become cohesive;

3. Constantly give challenging tasks with prompt and clear feedback (as it happens after Readiness Assurance Tests, which teachers gives students at the beginning of every new theme and application exercises).

These conditions, which fit constructivist didactic model where the role of the teacher is mostly as a facilitator, allow students to learn the content, to learn how to use the content, to learn about themselves and how to interact with each others on major tasks and what is more important how to keep on learning after the course is over (Fink, 2002, p.9), and what is particularly important for lifelong learning - it teaches the self-directness and self-determination in studies.

The aim of the article is to reflect the results of 4-year empirical research on team-based learning implementation in Business English in several higher institutions in Latvia, where participated 298 students, who mastered their skills and competences reaching an academic success through this approach and to investigate the results of empirical research on team-based learning application in other European Union universities by Business English teachers from Germany, Austria, Slovenia, Italy, Spain, Greece and France.

\section{Methodology}

The paper focuses on illustration of team-based learning implementation in Business English course in Latvia in 4 various institutions in the frames of PhD research. The research was conducted from September 2015 till May 2019. 
The participants of the empirical research in Latvia were:

- 127 first-year undergraduate students from the Faculty of Management, Latvian Business College

- 90 first and second-year students from the Faculty of Education and Faculty of Management, Riga Teacher Training and Educational Management Academy

- 25 first-year undergraduate students from the Faculty of Business Administration, Management College

- 56 first-year undergraduate students from the Faculty of Education and Faculty of Business, Management and Economics, University of Latvia;

Totally 298 participants, age was from 18 to 52 years old. The differentiation of participants by age is indicated in the Table 1 .

Table 1. Differentiation of participants by age

\begin{tabular}{|c|c|c|c|c|c|c|c|c|}
\hline$<\mathbf{2 0}$ & $\mathbf{2 0 - 2 5}$ & $\mathbf{2 5 - 3 0}$ & $\mathbf{3 0 - 3 5}$ & $\mathbf{3 5 - 4 0}$ & $\mathbf{4 0 - 4 5}$ & $\mathbf{4 5 - 5 0}$ & $\mathbf{5 0 - 5 5}$ & $\begin{array}{c}\text { Not } \\
\text { indicated }\end{array}$ \\
\hline $\mathbf{1 0} \%$ & $37 \%$ & $22 \%$ & $10 \%$ & $6 \%$ & $4 \%$ & $2 \%$ & $2 \%$ & $\mathbf{7} \%$ \\
\hline
\end{tabular}

As it is seen from the Table 1, the majority of participants were presented in the age gap from 20 to 30 years old, followed by age gaps from 30 to 40 years old.

The differentiation of participants by English Language Proficiency level is given in Table 2. varies from Level A to C.

Table 2. Differentiation of participants by English Language Proficiency level

\begin{tabular}{|c|c|c|c|c|c|c|}
\hline A1 & A2 & B1 & B2 & C1 & C2 & $\begin{array}{c}\text { Not } \\
\text { indicated }\end{array}$ \\
\hline $12 \%$ & $24 \%$ & $36 \%$ & $19 \%$ & $5 \%$ & $1 \%$ & $3 \%$ \\
\hline
\end{tabular}

It is clear, that THE majority of participants obtain A2-B1 level, A2 is not high enough to be able to study Business English easily.

In order to ensure the objectivity and validity of the research data, the following materials and documents were analyzed:

- 298 pre-course questionnaires to students from Latvia;

- 277 post-course questionnaires to students from Latvia;

- 8 questionnaires to educators (Germany, Austria, Slovenia, Italy, Spain, Greece and France); 
- 20 in-depth interviews to students from Latvia;

- 8 in-depth interviews to educators (Germany, Austria, Slovenia, Italy, Spain, Greece and France);

- 9 focus groups (Latvia);

- Lessons observations.

In the groups taught in Latvia were as local students as the students, who represented different foreign countries - India, Lebanon, Brazil, Nigeria, Sri Lanka, Uzbekistan, China, Kazakhstan, Russia, Ukraine, Cameroun.

Humanists (Pearson and Podeschi, 1999, Maslow, 1968; Rogers, 1969, Knowls, 1980, Swanson and Holton, 2005, Leonard, 2002), constructivists (Merriam and Caffarela, 2007; Doll, 1993; Fosnot and Perry, 2005; von Glasersfeld, 1995; Arnold, 2005; Patzold, 2011) as well as social learning theories (Rehrl \& Gruber, 2007; Belanger, 2011; Lave and Wenger, 1993; Michaelsen, 2014) were applied within the frame of this research.

The hypothesis of the research - team-based learning is appropriate to achieve the desired quality of learning and learners' achievements in skills for life-long learning. The following criteria were formulated to measure the students' achievements:

1. knowledge of Business English;

2. ability to work in a team;

3. acquisition of higher-level cognitive skills;

4. ability to learn independently and be self-determined in learning in lifetime;

5. ability to apply the course content in complex situations.

\section{Findings}

To investigate the outcome of TBL application in teaching business English according to the settled criteria, the analysis of the pre-course questionnaires, post-course questionnaires, focus groups and in-depth interview was made. The pre-course questionnaires included 13 open questions, the post-course questionnaires included 15 Likert scale questions and five open questions. The pre-course questionnaires were distributed at the beginning of the first lesson, the post-course questionnaires were distributed at the end of the last lesson of the course. All students simultaneously had to complete the printed questionnaires and submit it simultaneously at the end of the lesson. After that some groups were asked to stay and discuss the post-course questionnaires. The focus groups were formed from the students who participated in the course and completed both questionnaires. They were sitting in the circle and one by one discussed the questions from the questionnaires, explaining and commenting on their answers. 
The students who were taught by TBL in Latvia expressed their interest and satisfaction of this method - 'the method was great', 'I was very peaceful to come to your lessons', 'it is helpful', 'I find it interesting, something what we did not have before', 'it improves our knowledge', 'we were really into the working, discussions', 'we felt calm, positive, relaxed, excited a little bit, because we were not get disappointed', 'it let me feel more free and open-minded', 'I felt interested'.

They confirmed that TBL improved their 'communication', 'listening by listening to each other', 'vocabulary by listening to peers and picking up new words', 'grammar by understanding the mistakes of others'.

The analysis of the outcome of the TBL approach in Business English measuring the students' achievements according to the established criteria is presented in the following graph (Figure 1).

\section{Achievements Criteria}

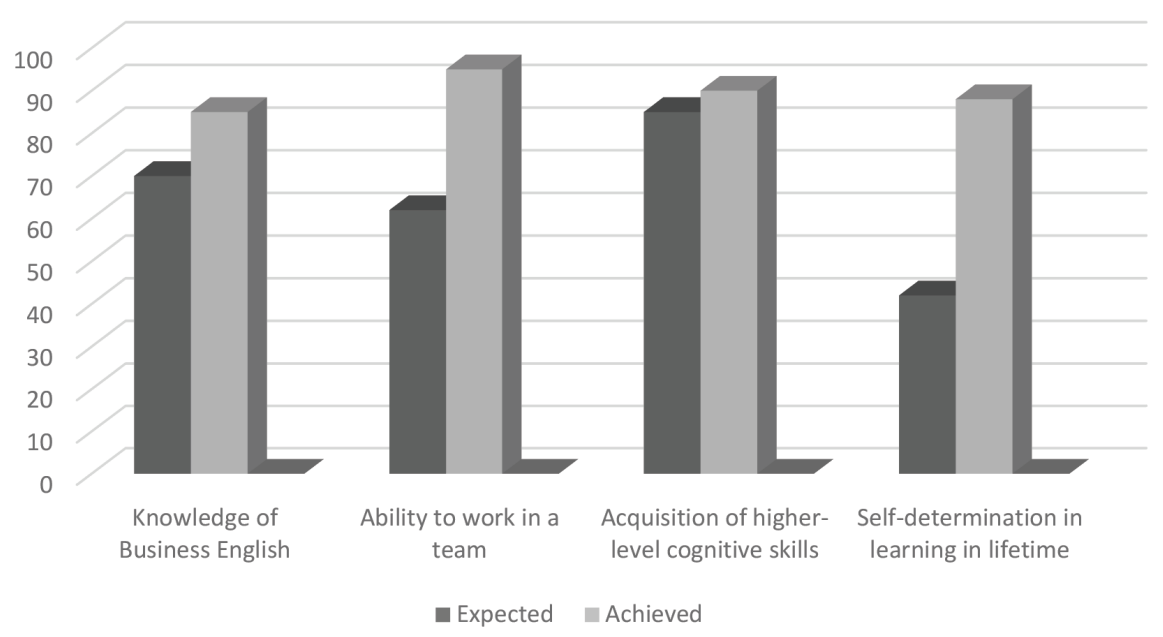

Figure 1. Analysis of TBL outcomes in Business English

Analyzing the results presented in Figure 1, it is possible to conclude that:

- $85 \%$ of students agree that the lessons, where TBL approach was used facilitated to their BE knowledge improvement (reading, listening, speaking, writing);

- $95 \%$ of students believe that the lessons increased their ability to work in teams;

- $90 \%$ confirm that the lessons improved their higher-level cognitive skills; 
- $88 \%$ of students agree that the lessons facilitated their selfdetermination in learning.

Thus, it is possible to sum up that by opinion of the students themselves their knowledge of Business English, ability to work in teams, acquisition of higher-level cognitive skills and development of self-determination in leaning in lifetime have progressed and improved in comparison with their expectations. They acknowledged that being taught by TBL they were able to master not only English knowledge but also acquired higher level cognitive skills, got an ability to learn independently and be selfdetermined in learning in lifetime, learned how to apply the course content in complex situations via communication and collaboration in teams. What proved team-based learning in teaching Business English to be a successful tool as it assisted to academic success in discipline, communication and understanding of the business environment peculiarities through teamwork and critical thinking. The research demonstrated that team-based learning gives more freedom and authorizes the students to be more responsible for their own studies and knowledge as the process involves both individual work and teamwork and the contribution to the team is significantly important there.

As this paper represents the definite stage of $\mathrm{PhD}$ research, it also investigates the results of empirical research on team-based learning application in other European Union universities by Business English teachers from Germany, Austria, Slovenia, Italy, Spain, Greece and France.

- Germany:University of Wurzburg, Faculty of Business Management and Economics;

- Austria:University of Vienna, Faculty of Business, Economics and Statistics;

- Slovenia:University of Ljubljana, Faculty of Economics;

- Italy: University of Florence, School of Economics and Management and University of Padua;

- Greece: University of Cyprus, Language Centre;

- France: University of Toulouse, School of Economics;

- Spain: University of Gerona, Centre of Modern Languages.

The choice of the Universities was random and it was connected with the willingness of the respondents to meet and to contribute to the research. The main purpose was to interview Business English language teachers to familiarize with their experience in teaching Business English. The method of triangulation was applied through questionnaires, interviews and observations.

Within the research were investigated: students English level, language teaching experience and approaches in teaching English, knowledge about 
team-based learning and its application, expected outcome and students' achievements from their BE course.

The Business English level of the students in the aforementioned Universities differs (see Figure 2), A2 (2 answers), B1 (3 answers), B2 (5 answers), C1 (4 answers), C2 (2 answers), thus, the majority of teachers teach groups with level B2-C1, which is high enough for team-based learning approach application.

It shows that the average level in other EU countries is higher than in Latvia, which makes it easier to teach Business English and to apply as TBL as any other communicative approaches.

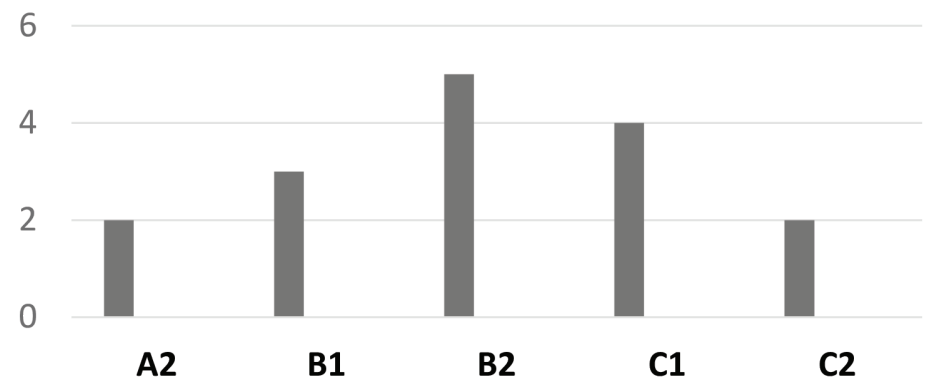

Figure 2. English Language Proficiency level in EU Universities

Having analyzed the teachers' language teaching experience and approaches in teaching English, as well as knowledge about team-based learning and its application, it is possible to make a conclusion that none of the interviewed teachers heard about TBL approach and consequently did not use it in lessons. However $75 \%$ of them (6 out of 8 ) replied positively on the question how they organize TBL, ("in every class", "every other lesson", "yes, during the semester I assign team-based assignment", "with a group and team activities", "yes, as often as possible with case studies/ simulations of meetings. At a lower levels smaller teams (2-3, at higher levels in bigger (5-6)). These answers make it possible to conclude that they all suppose that TBL is an equivalent to group-based learning, and that they do not fully realize what TBL is and how it differs from group learning or collaborative learning. The other two teachers who answered negatively, expressed their regret not using it and willingness to use it "not at all, I would be willing to try, though"), as they are not aware of what it is, as answering the question: "How do you organize TBL?" the teacher mentioned that "it depends on the task and how many will form the teams. Sometimes, the students can choose their own teammates, sometimes I assign or it is random". 
Answering the question: What is your opinion on the TBL, it is also possible to draw a conclusion that there are more positive feedbacks of this approach (75\%), as among the answers were "one excellent way to share and create skills for the students", "it is a positive experience for students and I use it in a lot of classes but I have my doubts about using teambased exams", "very positive", "my students do simulations of meetings and presentations in teams/groups. Learning in teams has some downsides (time-consuming, free-riders, mother tongue discussions), but there are also some upsides (peer learning, flexibility, interest, motivation).

On the other hand, in spite of the majority of the teachers claim they apply team-based approach, answering the question, which approach in teaching English they use, the answers differed, it means that teachers use all mentioned approaches, mixing and combining them in their course, what stands out, that 3 teachers acknowledge the use of teacher-centred approach, however at the same time they use student-centred approach too. Those teachers, who do not use teacher-centered approach, tend to combine different approach, creating the eclectic methods, involving games, projects, problem solutions but anyway targeting the student, who is in the centre. See the chart below (Figure 3).

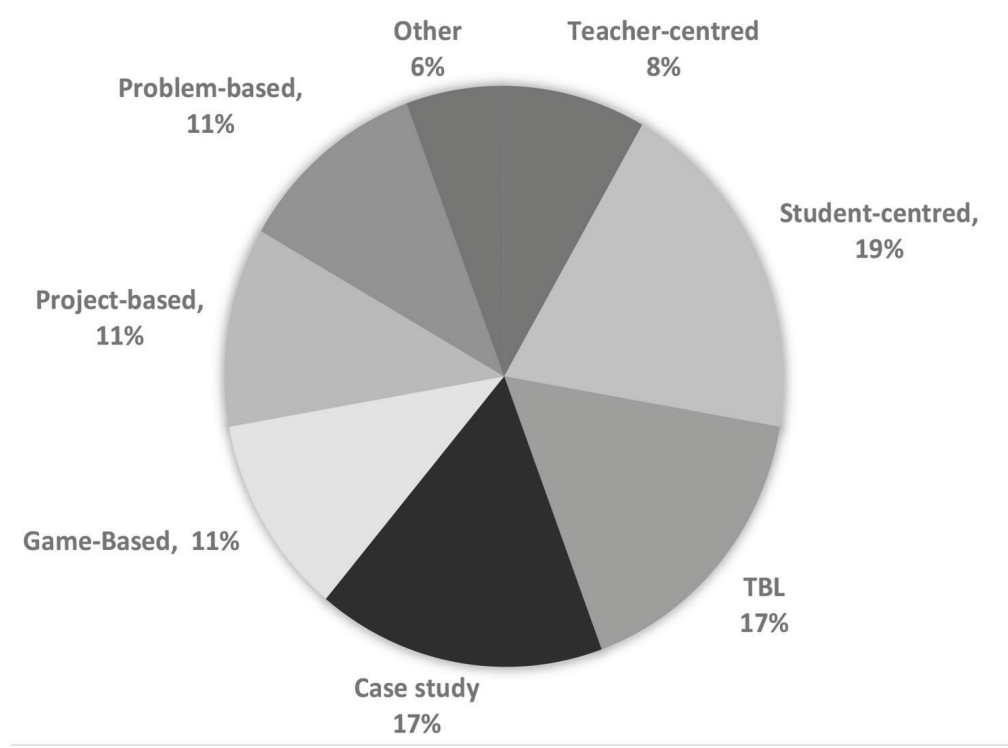

Figure 3. Approaches Used in EU Universities in BE

It is obvious that the most popular approach is student-centered, teambased and via case studies, however as it was mentioned earlier TBL approach is rather group-based. 
Among the achievements, which teachers expect from their students were indicated 12 skills, the main are represented in the chart (Figure 4).

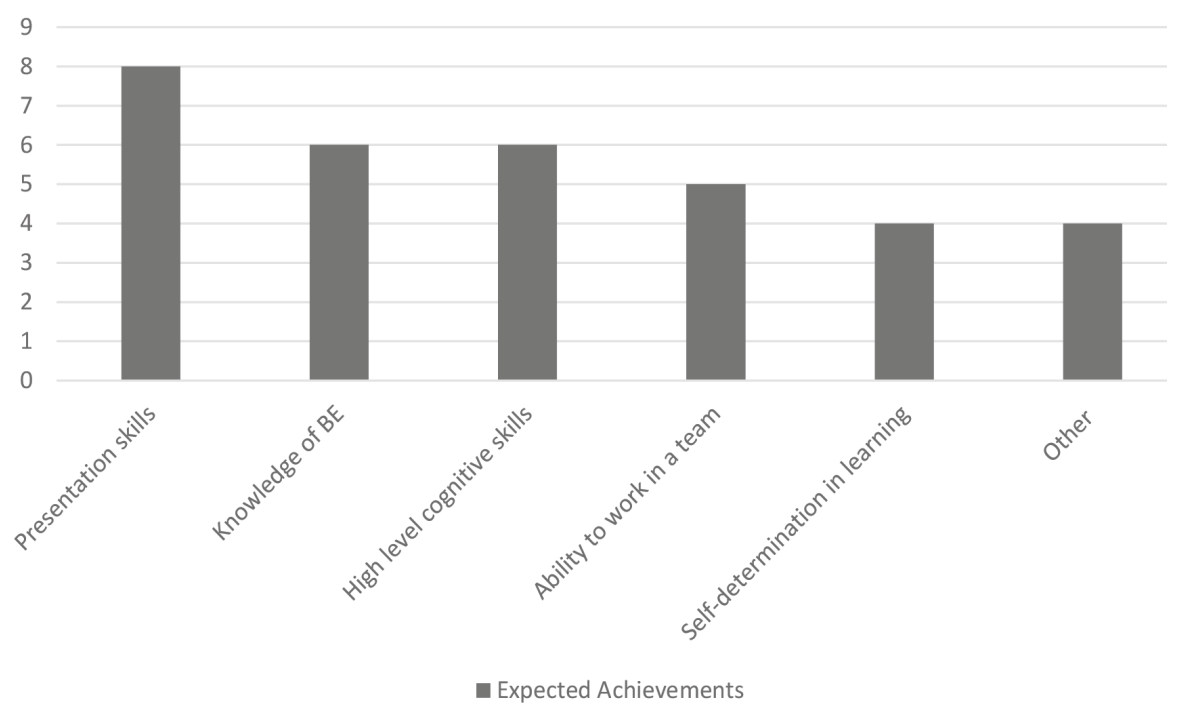

Figure 4. Expected Achievements in BE in EU Universities

Analyzing the expected achievements in Latvia (by students) and in EU universities (by teachers), it is possible to conclude that the main achievements are similar - knowledge of Business English, ability to work in a team, acquisition of higher-level cognitive skills, ability to learn independently and be self-determined in learning in lifetime. However the priorities differ insignificantly, for instance, presentation skills (absolutely all teachers mentioned "presentation skills" - 8 out of 8) which in Latvia are not prioritised at all in EU Universities are on the first place, also in other EU Universities teachers focus more on business vocabulary, on skills how to conduct the negotiation and chair the meetings. It means that all the aforementioned skills are considered by the teachers as valuable and reasonable to pay attention at the lessons, however with priority to business area (business vocabulary, presentations, negotiations, meetings). It is worth mentioning that some teachers added their own variants of achievements, which they expect:

- "To succeed at a job interview; to use politeness when communicate in English" (Cyprus)

- "ability to assess own progress, ability of accept own learning path, feeling confidence in speaking" (Girona)

- "foreign language communicative competences" (Ljubljana)

- "intercultural skills, soft skills" (Wurzbourg) 
These additional skills provides deeper into understanding what are the real expectations from Business English course in other EU countries. Also, it emphasises more hard-skills development approach, rather than soft skills. Nevertheless, in general expected achievement all teachers are unanimous.

Trying to figure out more about the realizaton by EU teachers TBL approach, the following question was asked: How do you organize TBL? The answers again emphasized that the teachers perceive TBL as a group work: "it depends on the aims of the activity, some times put students together with very different experiences, other time with similar experiences", " in groups of 4 students", "for debates, presentations, for researching topics - seminar with whole group", "with good instructions, help in the preparation stage, time to prepare at home and do some research individually, by providing feedback before/during/after the activity, providing students with safe environment for communicating and learning, organizing work in several teams at the same time to enable the potential experiential learning and self-evaluation". It demonstrates that in general group learning or collaborative learning prevails in the Business English classes in EU universities.

\section{Conclusions}

Team-based learning approach is a useful and transformative tool for teaching Business English. However, in spite of its very positive application in institutions of Latvia, this method is not familiar to other European Business English Language teachers. Moreover, completely all teachers, who participated in the research, substitute the notions collaborative learning/group learning with team-based learning.

The reasons could be the following:

- lack of information about TBL among language teachers;

- lack of information about TBL in Europe in general.

Besides, it was possible to notice, that:

- teachers of BE gradually have been changing their teaching approach from teacher-centered to student-centered'

- -even if the level of English in EU universities allows to apply different methods, such as TBL including;

- -BE teachers focus mostly on preparation for real life situations.

In order to facilitate the expansion of TBL in BE in Europe, the following possible solutions are applicable:

- to support BE teachers with information about new approaches.

- to spread the word about TBL in particular. 


\section{References}

Arnold, J. (2005). Work psychology: Understanding human behaviour in the workplace. ( $4^{\text {th }}$ ed.). London. UK: Prentice Hall Financial Times.

Balan, P., Clark, M., \& Restall, G. (2015). "Preparing students for Flipped or TeamBased Learning methods", Education + Training, 57 (6), 639-657. DOI: 10.1108/ ET-07-2014-0088.

Belanger P. (2011). Theories in Adult learning and education. Laverkusen Opladen. Germany Barbara Budrich ublishers.

Betta, M. (2016). "Self and others in team-based learning: Acquiring teamwork skills for business". Journal of Education for Business, 91 (2), 69-74. DOI: 10.1080/ 08832323.2015.1122562.

Bourdieu, P. (1990). Reproduction in Education, Society and Culture. Los Angeles. USA: SAGE Publishing.

Bouw, J. W., Gupta, V., \& Hincapie, A. L. (2015). "Assessment of students' satisfaction with a student-led team-based learning course". Journal of Educational Evaluation for Health Professions, 12-23. DOI: 10.3352/jeehp.2015.12.23.

Branney, J., Priego-Hernandez, J. (2018). "A mixed methods evaluation of team-based learning for applied pathophysiology in undergraduate nursing education". Nurse Education Today, 61, 127-133. DOI: 10.1016/j.nedt.2017.11.014.

Doll, W. (1993). A post-modern perspective on curriculum. New York. USA: Teachers College Press.

Edgerton, R. (2001). Education White Paper. Retrieved from http://www.faculty. umb.edu/john_saltmarsh/resources/Edgerton\%20Higher\%20Education\%20White\% 20Paper.rtf.

Fink, L. D. (2002). Beyond small groups: Harnessing the extraordinary power of learning teams. pp. 4-9. In L. K.

Michaelsen, A. B. Knight, \& L. D. Fink (Eds.), Team-based learning: A transformative use of small groups. Westport, CT: Praeger.

Fosnot, C. T. \& R. S. Perry (2005). Constructivism: A psychological theory of learning. pp. 8-38. In Fosnot, C.T. (Ed.): Constructivism. Theory, Perspectives, and Practice. 2nd edition. New York. USA: Teachers College.

Gruber, H., Palonen, T., Rehrl, M. \& Lehtinen, E. (2007). Understanding the nature of expertise: Individual knowledge, social resources and cultural context. pp. 227-250. In: Gruber, Hans and Palonen, Tuire, (eds.) Learning in the workplace - new developments. Research in educational sciences, 32. Turku. Finland: Finnish Educational Research Association (FERA).

Huggins, C. M., Stamatel, J. P. (2015). "An Exploratory Study Comparing the Effectiveness of Lecturing versus Team-based Learning". Teaching Sociology, 43(3), 227-235. DOI: 10.1177/0092055X15581929.

Illeris, K. (2004). Adult education and adult learning, London. UK: Routledge.

Imazeki. J. (2015). "Getting Students to Do Economics: An Introduction to Team-Based Learning". International Advances in Economic Research, 21, 399-412.DOI 10.1007/ s11294-015-9541-0.

Jarvis, P. (2004). Adult Education and Lifelong Learning: Theory and Practice. London and New York: Routledge.

Knowles, M. S. (1980). The modern practice of adult education: From pedagogy to andragogy (revised and updated). Englewood Cliffs, NJ: Cambridge Adult Education. 
Lave, J., Wenger E. (1993). Learning in Doing: Social, Cognitive and Computational Perspectives, Cambridge. UK: Cambridge University Press.

Leonard D., (2002) Learning theories A to Z. London. UK: Greenwood Press.

Liu, S-N. C., Beaujean, A. A. (2017). "The Effectiveness of Team-Based Learning on Academic Outcomes: A Meta-Analysis". American Psychological Association, 3 (1), 1-14. DOI: $10.1037 /$ stl0000075.

May, M. A., Doob, L. W. (1937). Competition and Cooperation. NY: Social science research council. Retrieved from https://babel.hathitrust.org/cgi/pt?id=mdp.3901500802380 9; view $=1$ up;seq $=1$.

Maslow, A. H. (1968). Toward a Psychology of Being. NY: USA: Litton Educational Publishing, Inc.

McClusky, H.Y. (1970). An Approach to a Differential Psychology of the Adult Potential. In Grabowski S. M. (Eds.) Adult learning and instruction. Syracuse, N.Y.: ERIC Clearinghouse on Adult Education.

Merriam, S., Caffarella, R., \& Baumgarther, L. (2007). Learning in Adulthood: A Comprehensive Guide. (p. 262). San Francisco. USA: San-Jossey-Bass.

Mezirow, J. (1991). Transformative Dimensions of Adult Learning. San Francisco, USA: Jossey-Bass Inc.

Michaelsen, L. K., Davidson, N., \& Major, C. H. (2014). Team-based learning practices and principles in comparison with cooperative learning and problem-based learning. Journal on Excellence in College Teaching, 25(3\&4), 57-84.

Nagaswami, S. V., Defouw, D. O., \& Compton. S. (2011). "Team-Based Learning in Anatomy: An Efficient, Effective, and Economical Strategy". Anatomical Sciences Education. DOI: 10.1002/ase.257.

Patzold, H. (2011). Learning and teaching in adult education. Contemporary theories. Laverkusen Opladen. Germany: Barbara Budrich Publishers.

Pearson, E. M., \& Podeschi, R. L. (1999). Humanism and individualism: Maslow and his critics. Adult education Quarterly, 50(1), 41-55.

Rodgers, C. (1969). Freedom to Learn, USA: Merrill.

Simonson, S. R. (2014). "Making students do the thinking: team-based learning in a laboratory course". Advances in Physiology Education, 38, 49-55, DOI:10.1152/ advan.00108.2013.

Stein, R. E., Colyer, C. J., \& Manning, J. (2016). "Student Accountability in Team-based Learning Classes”. Teaching Sociology, 44(1), 28-38. DOI: 10.1177/0092055X15603429.

Swanson, R. A., \& Holton, E. F. III. (Eds.) (2005). Research in organizations: Foundations and methods of inquiry. San Francisco: Berrett-Koehler.

Tough, A. M. (1967). Learning without a Teacher: A Study of Tasks and Assistance during Adult Self-Teaching Projects. Toronto, Canada: The Ontario Institute for Studies in Education. Retrieved from http://allentough.com/books/lwt/intro.pdf.

Von Glasersfeld, E. (1995). Radical Constructivism: A Way of Knowing and Learning. Studies in Mathematics Education Series: 6.

Wu, S., Farquhar, J., \& Compton, S. (2018). "Why do Team-Based Learning educators use TBL?". TAPS, 3(1), 38-41. DOI: 10.29060/TAPS.2018-3-1/SC1040.

Yoon, M. H., Burns, C. M. \& Michaelsen, V. E. (2014). 'Team-Based Learning in Different Classroom Settings". Medical Science Educator, 24, 157-160. DOI 10.1007/ s40670-014-0024-3. 